\title{
Effects of social capital on operational performance: Impacts of servitisation
}

\begin{abstract}
Studies on servitisation have largely overlooked the roles of social capital with suppliers and knowledge management. We propose a moderated mediation model to investigate the impacts of servitisation on the mechanisms through which social capital with suppliers improves operational performance. The hypotheses are empirically tested using structural equation modelling and data collected from 276 manufacturing firms in China. The results show that social capital improves operational performance both directly and indirectly through knowledge management, and the relationships are influenced by servitisation. In particular, social capital improves operational performance directly and indirectly through knowledge combination in servitised firms, whereas social capital only improves operational performance indirectly through knowledge acquisition in traditional manufacturers. The findings contribute to literature by revealing that the effects of social capital with suppliers on operational performance are partially mediated by knowledge acquisition and knowledge combination and the mediation effects are moderated by servitisation, and by providing insights into how to design purchasing and production systems to profit from servitisation.
\end{abstract}

Keywords: servitisation, social capital, knowledge management, supply chain management, empirical study 


\section{Introduction}

In response to increasing market dynamics and intensifying competition, manufacturing firms are adopting servitisation to achieve a better fit with customer requirements (Baines, Lightfoot, Benedettin, et al. 2009; Wise and Baumgartner 1999; Lightfoot, Baines, and Smart 2013). Servitised firms enrich product offerings through value-added services and satisfy customers through marketable product-service systems (Vandermerwe and Rada 1988; Oliva and Kallenberg 2003; Shen, Wang, and Sun 2012). However, although researchers argue that servitisation can lock in customers, lock out competitors, reduce costs and risks, and improve profitability and competitiveness (Raddats et al. 2016; Baines and Shi 2015), some firms are unable to profit from servitisation (Alghisi and Saccani 2015; Neely 2008).

Social capital refers to 'the sum of the actual and potential resources embedded within, available through, and derived from the network of relationships possessed by an individual or social unit' (Nahapiet and Ghoshal 1998, P. 243). Social capital with suppliers facilitates cooperation, allows a firm to influence suppliers' decisions, reduces the need for formal controls, and increases resources available to a firm (Carey, Lawson, and Krause 2011; Zhou et al. 2014; Matthews and Marzec 2012; Adler and Kwon 2002). There is empirical evidence that social capital with suppliers enables firms to improve performance and gain competitive advantages (e.g. Carey, Lawson, and Krause 2011; Wang, Ye, and Tan 2014; Lawson, Tyler, and Cousins 2008; Cousins and Lawson 2007; Villena, Revilla, and Choi 2011). Social capital also increases the anticipated value of, motivation to, and capabilities for knowledge exchange and combination, and improves the quality, relevance, and timeliness of the information flow in a supply chain, facilitating a firm to acquire 
knowledge from and assimilate knowledge together with suppliers (Nahapiet and Ghoshal 1998; Matthews and Marzec 2012). Hence, social capital with suppliers can influence a firm's performance both directly and indirectly by facilitating knowledge management (Wang, Ye, and Tan 2014; Zhang et al. 2015). In addition, empirical evidence exists that the effectiveness of social capital is influenced by contingencies (Villena, Revilla, and Choi 2011; Zhou et al. 2014). Researchers argue that servitisation changes the operational linkages between a firm and suppliers and firms need to develop new knowledge and cooperative relationships with suppliers to profit from servitisation (Opresnik and Taisch 2015; Kastalli and Van Looy 2013; Johnson and Mena 2008). However, there is limited empirical evidence on how servitisation influences the effectiveness of social capital and knowledge management (Bastl et al. 2012; Saccani, Visintin, and Rapaccini 2014).

The objective of this study is to empirically investigate how servitisation influences the effects of social capital with suppliers on operational performance. It aims to address the following two research questions. First, how do social capital, knowledge acquisition, and knowledge combination jointly affect operational performance? Second, how does servitisation influence such effects?

The remainder of this paper is organized as follows. In Section 2, we review the literature related to social capital, knowledge acquisition and knowledge combination, and servitisation, and develop research hypotheses. The research method is described in Section 3 and the empirical analyses and results are presented in Section 4. In Section 5, we discuss the key findings of the study and their theoretical and managerial implications, and outline the limitations and future research directions. 


\section{Literature review and research hypotheses}

\subsection{The direct effect of social capital on operational performance}

Nahapiet and Ghoshal (1998) propose that social capital has three dimensions: structural, cognitive, and relational capital. This study focuses on cognitive and relational capital as there is empirical evidence that structural capital does not directly influence operational performance (Villena, Revilla, and Choi 2011) and it improves performance outcomes indirectly through relational and cognitive capital (e.g. Li, Ye, and Sheu 2014; Zhang et al. 2015; Tsai and Ghoshal 1998; Carey, Lawson, and Krause 2011; Cousins et al. 2006). Relational capital refers to 'those assets created and leveraged through relationships' (Nahapiet and Ghoshal 1998, P. 244). It can be conceptualized as the trust and commitment between a firm and suppliers (Carey, Lawson, and Krause 2011). Cognitive capital refers to 'those resources providing shared representations, interpretations, and systems of meaning among parties' (Nahapiet and Ghoshal 1998, P. 244). It can be conceptualized as the common objectives and values and shared language and codes between a firm and suppliers (Villena, Revilla, and Choi 2011). Relational and cognitive capital are interrelated and they jointly create a high degree of solidarity, sustain relationships, and facilitate knowledge exchange and combination (Edelman et al. 2004; Tsai and Ghoshal 1998; Matthews and Marzec 2012).

Operational performance refers to the degree to which a firm's operations can achieve the goals of being right, fast, on time, productive, and able to change (Slack, Chambers, and Johnson 2010; Ward et al. 1998). We argue that social capital with suppliers enhances operational performance directly by facilitating supply chain cooperation (Flynn, Huo, and Zhao 2010; Yeung et al. 2009). In particular, social capital encourages suppliers' 
compliance with agreements and reduces the need for formal controls (Matthews and Marzec 2012). It also facilitates the identification with and internalization of a firm' goals and values, and hence suppliers can understand the actions taken by the firm (Adler and Kwon 2002). In this way, social capital allows a firm and suppliers to avoid misinterpretations of events and agree on expected outcomes of collaboration, and guarantees that suppliers fulfil obligation and behave predictably (Cousins et al. 2006; Krause, Handfield, and Tyler 2007). A supply chain can also develop a shared understanding of what constitutes improvement and how to accomplish it (Krause, Handfield, and Tyler 2007). As a relational lubricant for maintaining long-term cooperative relationships, social capital promotes mutually beneficial behaviour and reduces defections such as free riding, holdups, and leakages in supply chains (Edelman et al. 2004), enabling a firm to improve performance (Tsai and Ghoshal 1998). In addition, researchers have found that social capital can lead to improvement in cost, quality, delivery, and flexibility performance (Krause, Handfield, and Tyler 2007; Carey, Lawson, and Krause 2011; Villena, Revilla, and Choi 2011). Therefore, we propose the following hypothesis.

H1: Social capital with suppliers improves operational performance directly.

\subsection{The indirect effects of social capital on operational performance through knowledge}

\section{acquisition and knowledge combination}

Knowledge acquisition refers to a firm's ability to identify and obtain knowledge that is critical to its operations from suppliers (Zahra and George 2002; Hult, Ketchen, and Slater 2004). A firm can acquire knowledge by connecting with suppliers through information systems and by establishing routines and processes (e.g. special meetings or surveys) to interact with suppliers (Zhang et al. 2015). Knowledge combination refers to a 
firm's ability to synthesize current and acquired knowledge (Kogut and Zander 1992). A firm can combine knowledge through learning groups, interdepartmental meetings, knowledge distribution routines, and training programs (Zhang et al. 2015). Through these practices, knowledge acquired from suppliers is shared, given one or more commonly understood interpretations, and combined with existing knowledge (Zahra and George 2002; Hult, Ketchen, and Slater 2004).

Social capital with suppliers allows a firm to identify valuable knowledge in supply chains and gain access to the knowledge (Wang, Ye, and Tan 2014; Li, Ye, and Sheu 2014). In particular, compatible objectives and values help a firm and suppliers establish consistent perceptions as to how they should interact with one another, which lead to a common anticipation of and a strong foundation for knowledge exchange (Tsai and Ghoshal 1998). Common language and codes provide a conceptual appliance that facilitates a firm to recognize and evaluate suppliers' knowledge (Matthews and Marzec 2012). Trust can lead to a long-term relationship between a firm and suppliers (Ganesan 1994), which increases suppliers' confidence that the firm will use the received knowledge appropriately (Yeung et al. 2009). With high commitment, suppliers are more likely to invest in resources and take the risks associated with knowledge sharing (Brown, Lusch, and Nicholson 1995). Hence, social capital provides a firm access to suppliers' privileged knowledge and increases the frequency and quality of supply chain interactions, enhancing the breadth and efficiency of knowledge acquisition (Yeung et al. 2009; Wang, Ye, and Tan 2014).

The knowledge acquired from suppliers enables a firm to improve its operations (Zhou et al. 2014). A firm can acquire information and knowhow, such as production plans 
and inventory levels, feedback on product and process designs, and knowledge about new materials and equipment, from suppliers, which can be used to adjust and optimize operations to cope with changes in environments (Hult, Ketchen, and Slater 2004; Kogut and Zander 1992). In particular, frequent supplier surveys help a firm evaluate its supply chains, thereby allowing the firm to modify manufacturing processes and inventory levels according to feedback from suppliers. Focus groups and brainstorming sessions with suppliers enable a firm to obtain improvement suggestions and new ideas on product and process designs (Hult et al. 2006). Such knowledge allows the firm to continuously shorten production lead times and product development cycles, improve product quality, and reduce manufacturing costs ( $\mathrm{Li}, \mathrm{Ye}$, and Sheu 2014). In addition, network-based information systems allow a firm to acquire accurate and timely delivery and scheduling information from suppliers (Yeung et al. 2009). Thus, the firm can coordinate interorganizational processes and make effective production and delivery arrangements, which reduce inventory costs and improve dependability and speed (Slack, Chambers, and Johnson 2010). In this way, knowledge acquisition enables a firm to optimize supply chain processes, enhancing operational performance (Flynn, Huo, and Zhao 2010). Therefore, we propose the following hypothesis.

H2: Social capital with suppliers improves operational performance indirectly through knowledge acquisition.

Social capital with suppliers facilitates knowledge combination by helping a firm analyse, interpret, and transform the knowledge acquired from suppliers (Shu et al. 2012). In particular, common language and codes enable a firm to understand suppliers' internal operations, such as production systems and product and process development practices, 
which leads to overlapping knowledge bases and avoids distortions when the firm combines the knowledge acquired from suppliers (Zahra and George 2002; Matthews and Marzec 2012). Congruent objectives and trust increase suppliers' openness and motivate suppliers to make relationship specific investments for collaborative knowledge development (Brown, Lusch, and Nicholson 1995). The suppliers are more likely to spend efforts to articulate their knowhow, participate in a firm's knowledge management processes, and create knowledge together with the firm (Tsai and Ghoshal 1998; Zhang et al. 2016). These efforts reduce the ambiguity of suppliers' knowledge and help the firm interpret and internalize the acquired knowledge (Nahapiet and Ghoshal 1998). In this way, social capital helps a firm reach a deeper understanding of suppliers' knowledge and its applications, enhancing knowledge combination.

Knowledge combination enables a firm to synthesize its own and acquired knowledge to improve performance (Kogut and Zander 1992). Through cross-functional collaboration and team work, employees can process and internalize acquired knowledge together, which can lead to new knowledge and new applications of existing knowledge that improve operations (Hult, Ketchen, and Slater 2004; Jansen, Van Den Bosch, and Volberda 2005). In particular, learning groups enable employees to collaborate on analysing and interpreting the feedback, suggestions, and ideas learned from suppliers and on transforming them into action plans for continuous improvement and product and process innovation (Shu et al. 2012). Interdepartmental meetings allow employees to combine their opinions and suggestions, make joint decisions that incorporate everyone's ideas and expertise into product and process designs, and tackle the conflict caused by interdependency or discrepancy among departments (Flynn, Huo, and Zhao 2010; Zhang et al. 2015). In 
addition, training programs and knowledge distribution routines help employees grasp acquired knowledge and develop shared understandings about how to apply the knowledge into operations (Zahra and George 2002). Hence, knowledge combination can improve employees' skills and a firm's capabilities for creating new and improving current products, services, and processes, enhancing operational performance (Shu et al. 2012; Kogut and Zander 1992). Therefore, we propose the following hypothesis.

H3: Social capital with suppliers improves operational performance indirectly through knowledge combination.

Knowledge acquisition can bring a firm new knowledge, including new materials and their applications, competitors' innovations, and market and technology development trends, which may be beyond employees' existing knowledge domain and past experiences (Zhang et al. 2015). The acquired new knowledge motivates a firm to implement specialized procedures and mechanisms to assimilate, transform, and integrate it with the firm's existing knowledge base (Jansen, Van Den Bosch, and Volberda 2005). In addition, knowledge acquisition provides inputs or 'raw materials' for knowledge combination (Kogut and Zander 1992). Thus, knowledge acquisition increases a firm's expectation on the value of and drives the firm to invest in knowledge combination (Nahapiet and Ghoshal 1998). Therefore, we propose the following hypothesis.

H4: Knowledge acquisition is positively associated with knowledge combination.

\subsection{The moderating effects of servitisation on the impacts of social capital on operational performance}

Servitisation refers to a firm's capabilities and processes to shift from selling products to selling integrated products and services (Baines, Lightfoot, Benedettin, et al. 2009; 
Lightfoot, Baines, and Smart 2013). Based on case studies, researchers have found that servitisation requires a firm to develop new knowledge and build close and cooperative relationships with suppliers. For example, Johnson and Mena (2008) find that servitised firms need to improve the responsiveness of their supply chains, develop processes for realtime information sharing with suppliers, and establish long-term agreements with strategic suppliers. Bastl et al. (2012) show that servitisation requires more open information exchange, strengthened operational linkages, and increased levels of supplier adaptation in a supply chain. Baines and Lightfoot (2013) discover that supplier relationships and integration is one of the distinct practices for servitisation. Alghisi and Saccani (2015) show that the challenges of servitisation include supplier interface capabilities and knowledge management. Baines and Shi (2015) also find that strong relationships with suppliers are critical enablers for servitisation.

We argue that the direct effect of social capital on operational performance is stronger in servitised firms. Servitisation requires a firm to respond quickly to customers' personalized requirements through the development and delivery of value-added services or product-service systems (Baines, Lightfoot, Peppard, et al. 2009; Johnson and Mena 2008). Hence, compared with traditional manufacturers who mainly produce tangible goods, servitised firms emphasize more on establishing long-term relationships and collaborating with suppliers (Zhang et al. 2016; Baines and Shi 2015). In particular, servitisation increases the complexity and diversity of a firm's operations (Smith, Maull, and $\mathrm{Ng} 2014$ ) and requires more support from suppliers because services are characterized by intangibility, heterogeneity, inseparability, and perishability, and are customized to satisfy customers' special requirements (Benedettini, Swink, and Neely 2015; Kastalli and 
Van Looy 2013). Thus, servitised firms must expand their resource and knowledge bases, which are dependent on suppliers' capabilities and commitment (Baines, Lightfoot, Benedettin, et al. 2009; Alghisi and Saccani 2015). Suppliers must also extend their offerings and be involved in a servitised firm's internal operations and hence they play more important roles in influencing the firm's operational performance (Saccani, Visintin, and Rapaccini 2014). In this way, social capital, which can facilitate relational exchange and collaboration with suppliers, has stronger impacts on operational performance in servitised firms compared with traditional manufacturers.

We also argue that the indirect effects of social capital on operational performance through knowledge acquisition and knowledge combination are stronger in servitised firms. Servitised firms focus on volatile market segments and aim to profit from market dynamics (Lightfoot, Baines, and Smart 2013; Oliva and Kallenberg 2003). Servitisation also requires innovative product and service designs and new insights into markets (Opresnik and Taisch 2015; Wise and Baumgartner 1999). Thus, the implementation of servitisation exerts greater pressure on firms to create new knowledge for operational process improvement (Bastl et al. 2012; Alghisi and Saccani 2015). Knowledge acquisition enables a firm to sense and respond to changes in supply chain environments, helping servitised firms adjust operations and product and service designs swiftly (Zhang et al. 2015; Hult et al. 2006). Through knowledge combination, a firm can create new knowledge or new applications of existing knowledge that can lead to new product, service, and process designs to deal with the rising complexity and variety associated with servitisation (Hult, Ketchen, and Slater 2004). The new knowledge obtained from suppliers or created internally also allows a firm to integrate products and services creatively (Wang et al. 2011; 
Johnson and Mena 2008). Servitisation thus enables a firm to take full advantage of its knowledge management efforts. In contrast, traditional manufacturers mainly use new knowledge for product development and delivery and thus cannot realize its value on service innovation. Hence the effects of knowledge acquisition and knowledge combination on operational performance are stronger in servitised firms compared with traditional manufacturers (Smith, Maull, and Ng 2014). In this way, we argue that social capital with suppliers plays a more important role in improving operational performance both directly and indirectly through knowledge acquisition and knowledge combination in servitised firms. Therefore, we propose the following hypothesis.

H5: The effects of social capital with suppliers on operational performance are stronger in servitised firms.

The conceptual model and all proposed hypotheses are provided in Figure 1.

[Figure 1 about here]

\section{Research method}

This study aims to empirically investigate the impacts of servitisation on the joint effects of social capital, knowledge acquisition, and knowledge combination on operational performance. This is a contemporary issue and we do not have control over firms' behaviour. In addition, this is an explanatory research because we want to examine and explain the relationships among servitisation, social capital, knowledge acquisition, knowledge combination, and operational performance and the hypotheses are developed based on existing literature. Hence, questionnaire survey was used to conduct this study (Saunders, Lewis, and Thornhill 2015). 


\subsection{Questionnaire design}

Based on the relevant literature and research framework, a survey instrument was designed to measure a manufacturing firm's social capital with suppliers, knowledge acquisition and combination practices, and operational performance. A multiple-item, 7point Likert-type scale was employed to measure the constructs. The scales, which consist of 23 measurement items, are listed in the appendix. A dichotomous variable was used to measure servitisation. In addition, the questionnaire included the demographic profile of the manufacturing firms such as industry, ownership, size, and location.

Social capital was measured using seven items regarding trust, relationship commitment, compatible objectives and visions, shared values and culture, and common understandings about concepts and codes between a firm and suppliers (Nahapiet and Ghoshal 1998; Villena, Revilla, and Choi 2011). They were developed based on the studies by Carey, Lawson, and Krause (2011), Brown, Lusch, and Nicholson (1995), and Ganesan (1994). The items were adapted for buyer-supplier relationships. Knowledge acquisition was measured using four items regarding the routines, procedures, and information systems for interacting with suppliers (Zahra and George 2002). They were developed based on the studies by Jansen, Van Den Bosch, and Volberda (2005) and Hult, Ketchen, and Slater (2004). The respondents were asked to assess the social capital and knowledge acquisition with their main suppliers. Knowledge combination was measured using five items related to the mechanisms and processes used to analyse, interpret, distribute, and integrate knowledge within a firm (Nahapiet and Ghoshal 1998). Two items gauging group learning and knowledge distribution were adapted from Jansen, Van Den Bosch, and Volberda (2005) and three items on interdepartmental meetings, training, and knowledge integration 
were added based on the studies by Nahapiet and Ghoshal (1998) and Zahra and George (2002). The respondents were asked to indicate the extent to which they agree with the statements related to social capital, knowledge acquisition, and knowledge combination (1 $=$ 'strongly disagree'; $7=$ 'strongly agree'). Operational performance was measured using seven items to capture a firm's performance on cost, quality, delivery, and flexibility (Slack, Chambers, and Johnson 2010). The measures for operational performance were adapted from Ward et al. (1998) and Flynn, Huo, and Zhao (2010). The respondents were asked to indicate their firms' performance on these items compared with those of their competitors (1= 'much worse'; 7 = 'much better'). Servitisation was measured by one question about whether firms provide value-added services or product-service systems to customers (Yes= servitised firm; $\mathrm{No}=$ traditional manufacturer), which was developed based on the studies by Neely (2008), Baines, Lightfoot, Benedettin, et al. (2009), and Lightfoot, Baines, and Smart (2013).

Industry and firm size were included as control variables in the analysis (Zhang et al. 2015). The available technologies, clockspeed, and competition intensity in a given industry may affect operational performance of firms (Ward et al. 1998). The industry was measured by three dummy variables representing four industries. Large firms are more likely to have higher capabilities than small ones due to additional resources, which may lead to higher operational performance (Zhang et al. 2015). Hence, we also controlled firm size, which was measured by five dummy variables according to the number of employees. The details of the control variables are shown in Table 1.

The English version of the questionnaire was first developed and subsequently translated into Chinese by an operations management professor. The Chinese version was 
then translated back into English by another operations management professor. This translated English version was then checked against the original English version for any discrepancies, and adjustments were made to reflect the original meaning of the questions in English. The questionnaire was pilot tested using a sample of 13 manufacturing firms. The researchers discussed the survey questions face-to-face with managers after they filled out the questionnaire and clarified the meaning of the questions with them. When there was any confusion, the wording of the questions was modified.

\subsection{Sampling and data collection}

To test the proposed hypotheses, manufacturing firms were randomly selected from four industries (i.e. textile and apparel, electrical appliances, electronics and communication equipment, and automobile) in four major areas (i.e. Pearl River Delta, Yangtze River Delta, Bohai Sea Economic Area, and Central China) representing the national economy of China. We used the database provided by CSMAR Solution (http://csmar.gtadata.com/) as the sampling frame.

We conducted this survey in China for two reasons. First, Chinese culture is characterized by collectivism and long term orientation (Li, Ye, and Sheu 2014; Wang, Ye, and Tan 2014) and China lacks well-developed market-supporting institutions (Zhou et al. 2014; Shu et al. 2012). Thus, social capital with suppliers play critical roles for a firm to acquire knowledge from suppliers and manage supply chain collaboration in China (Adler and Kwon 2002; Zhang et al. 2015). Second, after decades of high speed economic growth, China has become a global manufacturing powerhouse. Chinese government has introduced policies for a great leap forward in transforming to a knowledge economy. A growing number of Chinese manufacturers are moving up value chains, investing heavily 
in innovation, and implementing advanced manufacturing practices such as servitisation (Zhang et al. 2016; Neely 2008). Opresnik and Taisch (2015) point out that servitised firms in China has risen from 1\% in 2007 to $20 \%$ in 2011. In addition, China's Ministry of Industry and Information Technology has developed a plan (i.e. Made in China 2025), which has set strategic objectives that by 2025 , the manufacturing value-added rate will achieve 4\% increase over 2015 and the average manufacturing labour productivity growth will be $6.5 \%$. Servitisation has been identified as an important way to increase Chinese manufacturers' productivity and competitiveness in the plan. For example, the Chinese government has formulated guidelines to promote service-oriented manufacturing, encouraged manufacturing firms to invest in services and develop customized services, and supported eligible firms to evolve from equipment providers into integrated system contractors and from product providers into total solution providers. Therefore, China provides an interesting context to empirically investigate how servitisation influences the effects of social capital on operational performance.

After pilot-testing the questionnaire, it was decided to use one key respondent per firm, who had the knowledge of supplier relationships and was familiar with knowledge management practices and operational processes. Such key respondents included supply chain managers, production managers, research and development managers, presidents, senior executives, and directors. Selected firms were contacted by telephone to identify the name and contact information of the most suitable respondent who was then sent the questionnaire, along with a cover letter highlighting the objectives of the research and its potential contributions to the respondent. Follow-up telephone calls were made to improve the response rate, and respondents were contacted to clarify missing data in their responses. 
We sent questionnaires to 1,460 randomly selected firms, but 133 of them were returned unopened. We finally collected 276 usable questionnaires. The response rate is therefore 20.8\%. The sample demographics are shown in Table 1.

\section{[Table 1 about here]}

Because the survey data was obtained from single respondents, common method bias might be a concern. Following Podsakoff et al. (2003), Harman's single factor test was performed on the social capital, knowledge acquisition, knowledge combination, and operational performance variables using exploratory factor analysis. The results showed that four distinct factors with eigenvalues above or near 1.0 explained $67.6 \%$ of total variance and that the first factor did not explain the majority of the total variance, which were acceptable for this study where the constructs were correlated, both conceptually and empirically (Flynn, Huo, and Zhao 2010).

\section{Analysis and results}

Partial least squares (PLS) is chosen to conduct the data analyses. The main reasons for selecting PLS rather than covariance-based structural equation modelling (CBSEM) are the research objective and model complexity (Peng and Lai 2012). There is no well-established theory on the impacts of servitisation on the relationships between social capital and operational performance. Hence, we focus on exploring the relationships between constructs rather than how well the empirical data fits the theoretical model. In addition, we propose a complex research model because it includes both mediation and moderation analyses. This increases the sample size requirement in CBSEM (Peng and Lai 2012). 
We use SmartPLS 2.0 M3 software to assess the measurement and structural models. We also apply a bootstrapping estimation procedure, in which 500 random samples of observations with replacements are generated from the original data set, to examine the significance of the scale factor loadings in the measurement model and that of the path coefficients in the structural models (Chin 2010).

\subsection{Measurement model}

A confirmatory factor analysis (CFA) is conducted using PLS. The CFA results are then used to analyse the reliability, convergent validity, and discriminant validity of the multiple-item scales (Peng and Lai 2012). Reliability is assessed in terms of composite reliability and Cronbach's alpha. In the measurement model, the composite reliabilities range from 0.879-0.895 and the Cronbach's alpha ranges from 0.818-0.862 (appendix), which are all above the recommended threshold value of 0.70 (Nunnally and Bernstein 1994), suggesting adequate reliability.

We assess convergent validity in terms of the average variance extracted (AVE) (Chin 2010). The results show that all of the AVE values are above the recommended value of 0.50 (ranging from 0.540-0.648), demonstrating adequate convergent validity (Fornell and Larcker 1981). In addition, all item loadings are greater or slightly smaller than 0.7 (appendix), and the smallest t-statistic of the factor loadings is 12.038 , which is significant at the $\mathrm{p}<0.01$ level, also suggesting adequate convergent validity (Chin 2010).

Discriminant validity is assessed by comparing the square roots of the AVE of each construct with the correlations between the focal construct and every other construct, with a square root higher than the correlation with other constructs suggesting discriminant validity (Fornell and Larcker 1981). A comparison of all of the correlations and square 
roots of the AVEs indicates adequate discriminant validity for all constructs (Table 2). In addition, the loading of each indicator is greater than all of its cross-loadings, which also indicates discriminant validity on the indicator level (Chin 2010).

[Table 2 about here]

\subsection{Structural model}

PLS is also used to examine the structural models. We first test the research model using the whole sample, and the path coefficients and $\mathrm{R}^{2}$ are presented in Figure 2. This model explains $31.7 \%$ of the operational performance variance $\left(\mathrm{R}^{2}\right)$, indicating that the model has adequate predictive power (Chin 2010). The effects of the control variables (i.e. industry and firm size) are not significant. We find that social capital significantly affects operational performance $(b=0.262, \mathrm{p}<0.05)$. Knowledge acquisition enhances knowledge combination $(b=0.439, \mathrm{p}<0.05)$. The results reveal that social capital is positively associated with knowledge acquisition $(b=0.633, \mathrm{p}<0.05)$ and knowledge combination $(b=0.219, \mathrm{p}<0.05)$. Knowledge acquisition improves operational performance $(b=0.259$, $\mathrm{p}<0.05)$. However, the effect of knowledge combination on operational performance is not significant. To determine whether knowledge acquisition carries the effect of social capital on operational performance, we calculate the indirect effect by multiplying the path coefficient from social capital to knowledge acquisition and that from knowledge acquisition to operational performance (Zhang et al. 2015). The indirect effect is $0.633^{*} 0.259=0.164$. Sobel's Z-test is then applied to assess the significance of the indirect effect. The resultant $Z$ value shows that the indirect effect is significant at the $\mathrm{p}<0.05$ level.

[Figure 2 about here] 
Next, we divide the sample into two subsamples according to whether servitisation has been implemented in a firm (i.e. servitised firm $(n=132)$ and traditional manufacturer $(\mathrm{n}=144))$. A PLS multiple-group analysis is conducted and the results are reported in Table 3. The research model is estimated in each subsample and the path coefficients are compared between the two subsamples using Chin (2000)'s approach. The results show that the effects of social capital on knowledge acquisition and knowledge combination are significant in both groups. We find that in the servitised firm group: the direct effect of social capital on operational performance is significant $(b=0.369, \mathrm{p}<0.05)$; the effect of knowledge combination on operational performance is also significant $(b=0.200, \mathrm{p}<0.05)$ and the indirect effect of social capital on operational performance through knowledge combination is $0.248 * 0.200=0.050$, which is significant at the $\mathrm{p}<0.05$ level; the effect of knowledge acquisition on knowledge combination is significant $(b=0.365, \mathrm{p}<0.05)$; however, the effect of knowledge acquisition on operational performance is not significant. We also find that in the traditional manufacturer group: the effect of knowledge acquisition on operational performance is significant $(b=0.299, \mathrm{p}<0.05)$ and the indirect effect of social capital on operational performance through knowledge acquisition is $0.556 * 0.299=0.166$, which is significant at the $p<0.05$ level; the effect of knowledge acquisition on knowledge combination is significant $(b=0.488, \mathrm{p}<0.05)$; however, the direct effects of social capital and knowledge combination on operational performance are not significant. The multiplegroup analysis further reveals that the effects of social capital on knowledge acquisition and knowledge combination, and the effect of knowledge acquisition on knowledge combination are not significantly different between the two groups; the effects of social capital and knowledge combination on operational performance are significantly stronger 
in the servitised firms; and the effect of knowledge acquisition on operational performance is significantly stronger in the traditional manufacturers. Hence, $\mathrm{H} 4$ is supported in both servitised firms and traditional manufacturers. In the servitised firms, $\mathrm{H} 1$ and $\mathrm{H} 3$ are supported but $\mathrm{H} 2$ is not, whereas in the traditional manufacturers, $\mathrm{H} 2$ is supported but $\mathrm{H} 1$ and $\mathrm{H} 3$ are not. In addition, the findings reveal that the total effects of social capital on operational performance are stronger in the servitised firms $\left(\mathrm{R}^{2}=0.498\right)$ than those in the traditional manufacturers $\left(\mathrm{R}^{2}=0.214\right)$. Therefore, $\mathrm{H} 5$ is partially supported.

[Table 3 about here]

\section{Discussion and conclusions}

\subsection{The direct effect of social capital on operational performance}

The results show that the direct effect of social capital on operational performance is moderated by servitisation and only significant in servitised firms. The findings are consistent with existing results that social capital is positively associated with performance outcomes (Li, Ye, and Sheu 2014; Zhang et al. 2015) and the relationships between social capital and performance are moderated by contingencies (Carey, Lawson, and Krause 2011; Villena, Revilla, and Choi 2011). Traditional manufacturers focus on goods production. They purchase raw materials or components from suppliers and then transform them into final products which are sold to customers (Slack, Chambers, and Johnson 2010). Traditional manufacturers can modularize product and process designs and postpone pushpull boundary to the downstream of a supply chain (Zhang et al. 2015). Hence, they can standardize and simplify upstream supply chain processes. In this way, supply chain cooperation may play a limited role in improving traditional manufacturers' operations. 
Firms must make investments in establishing and maintaining social capital with suppliers (Adler and Kwon 2002; Villena, Revilla, and Choi 2011). For traditional manufacturers, the costs of social capital may exceed its benefits and hence social capital with suppliers cannot enhance operational performance. Servitised firms must build complex supply chains to fulfil every customer's special requirements (Smith, Maull, and Ng 2014; Raddats et al. 2016). The development and delivery of value-added services or product-service systems are interactive and iterative processes that require suppliers' direct participation (Bastl et al. 2012; Alghisi and Saccani 2015). In addition, the implementation of servitisation is knowledge-intensive and sometimes requires suppliers to design new products and services (Baines, Lightfoot, Peppard, et al. 2009; Shen, Wang, and Sun 2012). Hence, servitisation requires more resources exchange and coordination in a supply chain (Bastl et al. 2012; Johnson and Mena 2008). Social capital with suppliers reduces uncertainties and transaction costs in a supply chain and facilitates cooperative behaviour and actions that in favour of collective interests (Cousins et al. 2006; Carey, Lawson, and Krause 2011). Therefore, social capital with suppliers is very valuable for the development and delivery of integrated products and services and hence can directly improve operational performance in servitised firms.

\subsection{The indirect effects of social capital on operational performance through knowledge acquisition and knowledge combination}

We find that the indirect effects of social capital on operational performance are also moderated by servitisation and social capital improves operational performance indirectly through knowledge acquisition in traditional manufacturers whereas through knowledge combination in servitised firms. The results are consistent with existing findings that 
knowledge management mediates social capital's effects (Tsai and Ghoshal 1998; Shu et al. 2012). Social capital with suppliers provides a frame of reference for information sharing, which reduces potential misunderstandings during knowledge acquisition and helps a firm engage in cooperative interactions with suppliers and gain access to their private information (Nahapiet and Ghoshal 1998; Carey, Lawson, and Krause 2011). Suppliers are also more willing to share information without worrying that they will be taken advantage of by partners (Zhang et al. 2015; Yeung et al. 2009). Hence social capital helps both traditional manufacturers and servitised firms acquire knowledge from suppliers. A firm can obtain both information and knowhow from suppliers (Hult et al. 2006). As traditional manufacturers tend to purchase modules and components with pre-defined specifications from suppliers for goods production, suppliers contribute to their operational performance by providing information, such as production and delivery scheduling and inventory levels, which is explicit and usually within the firms' extant knowledge domain (Flynn, Huo, and Zhao 2010; Zhang et al. 2015). The information can be utilised directly to plan and optimize operations and there is no need to analyse and combine such information using special procedures and mechanisms (Zhang et al. 2015). Hence social capital improves operational performance indirectly through knowledge acquisition in traditional manufacturers. In contrast, servitised firms usually offer customised productservice systems and value-added services which are dependent on knowhow, such as new ideas on service designs, suggestions on how to integrate products and services creatively, and opinions on market and technology development trends (Baines, Lightfoot, Benedettin, et al. 2009; Kastalli and Van Looy 2013). The knowhow is tacit and usually beyond firms' past experiences. Thus, it must be processed and combined with existing knowledge before 
it can be applied to improve operational performance (Hult, Ketchen, and Slater 2004; Zahra and George 2002). The analysis further reveals that in the servitised firms, knowledge acquisition significantly improves operational performance indirectly through knowledge combination $\left(0.365^{*} 0.200=0.073, \mathrm{p}<0.05\right)$.

Social capital can establish congruent systems of meaning, compatible technological trajectories and market forecasting, and overlapping knowledge bases, and can increase behaviour transparency in a supply chain, enhancing a firm's information processing capabilities (Zhang et al. 2015). Social capital can also provide appropriate incentives to foster suppliers to invest in resources to participate in a firm's internal knowledge management, enabling the firm to develop a deeper understanding of the knowledge obtained from suppliers (Tsai and Ghoshal 1998; Carey, Lawson, and Krause 2011). Thus, social capital improves knowledge combination in both servitised firms and traditional manufacturers. Traditional manufacturers mainly rely on the explicit information acquired from suppliers to improve operations and hence knowledge combination does not carry social capital's effects. Because servitisation requires a supplier to provide knowhow that must be absorbed and combined (Zhang et al. 2016; Shen, Wang, and Sun 2012), social capital enhances operational performance indirectly through knowledge combination in servitised firms. We also find that knowledge acquisition improves knowledge combination in both traditional manufacturers and servitised firms, which is consistent with existing empirical evidence (Zhang et al. 2015; Hult, Ketchen, and Slater 2004). The results reveal that knowledge acquisition and knowledge combination are interrelated. Applying technologies and practices for acquiring knowledge from suppliers and combining knowledge internally at the same time enables a firm to capture the synergic effects. 


\subsection{Theoretical contributions}

This study contributes to production research literature in two ways. First, this study links servitisation with social capital and knowledge management and provides insights into how to design purchasing and production systems to profit from servitisation (Neely 2008; Benedettini, Swink, and Neely 2015; Kastalli and Van Looy 2013). It provides empirical evidence that social capital with suppliers enhances operational performance both directly and indirectly through knowledge combination in servitised firms. The results reveal that the design of purchasing and production systems in servitised firms should include technologies and practices for developing and maintaining social capital with suppliers and knowledge combination (Johnson and Mena 2008; Shen, Wang, and Sun 2012). In addition, this study shows that firms that only focus on acquiring knowledge from suppliers without social capital with suppliers or internal procedures for knowledge combination are not able to profit from servitisation, which provides a possible explanation for why the adoption of servitisation does not always produce the returns that firms expect (Benedettini, Swink, and Neely 2015; Alghisi and Saccani 2015).

Second, this study shows that the effects of social capital on operational performance are partially mediated by knowledge acquisition and combination, which are moderated by servitisation. The results enhance extant knowledge on under what conditions social capital improves operational performance and provide insights into the inconclusive findings on the effectiveness of social capital (Edelman et al. 2004; Zhou et al. 2014; Villena, Revilla, and Choi 2011). The findings show that a firm should incorporate technologies and practices for knowledge acquisition and combination into purchasing and production systems to reap the full benefits of social capital with suppliers, extending existing 
knowledge on the impact of social capital on production system design (Matthews and Marzec 2012; Wang, Ye, and Tan 2014). In addition, the findings reveal that the purchasing and production systems for servitised firms and traditional manufacturers should focus on different supply chain relationship and knowledge management practices, providing empirical evidence that the alignment among supply chain relationships, knowledge management practices, and servitisation of manufacturing is particularly critical for a manufacturing firm to gain competitive advantages (Wang et al. 2011; Lightfoot, Baines, and Smart 2013).

\subsection{Managerial implications}

This study also provides managerial guidelines about how to design purchasing and production systems to profit from social capital with suppliers and the implementation of servitisation. First, technologies and practices that enable a firm to build social capital with and acquire knowledge from suppliers and to combine knowledge internally should be applied in purchasing and production systems. In particular, we suggest purchasing departments organise formal and informal social events, such as training programs, workshops, conferences, and seminars, to interact and establish common understandings about concepts and codes with suppliers. Purchasing departments should also organise focus groups and brainstorming sessions with suppliers and frequently survey suppliers. Procedures should be created in purchasing systems to evaluate suppliers' values and objectives and a firm should collaborate and establish strategic relationships with the suppliers who have compatible culture and visions, and have considered its interests and viewed the firm as a team member. We suggest that purchasing departments build networkbased information systems to acquire information and knowledge from suppliers in real 
time and databases to record past collaboration experiences with suppliers. In addition, internal knowledge management practices, such as learning groups, interdepartmental meetings, knowledge distribution routines, and training programs, should be included in a firm's production systems.

Second, managers should be aware that the purchasing and production systems in servitised firms and traditional manufacturers should focus on different supply chain and knowledge management technologies and practices. In particular, for traditional manufacturers, we suggest them develop network-based information systems and organise regular meetings with suppliers to obtain information. Managers in traditional manufacturers should be aware that purchasing systems that only focusing on building social capital with suppliers cannot help their firms improve operational performance. Purchasing systems in traditional manufacturers should implement technologies and practices for developing social capital with and acquiring knowledge from suppliers simultaneously. For the manufacturers who are or are considering implementing servitisation, we suggest them develop purchasing systems to build and maintain social capital with suppliers. In addition, it is critical for servitised firms to incorporate technologies and practices for knowledge combination in production systems at the same time.

\subsection{Limitations and future research directions}

This study has three main limitations, which open up avenues for future studies. First, this study is conducted in China. Researchers argue that the effects of social capital can be influenced by cultural and institutional environments (Li, Ye, and Sheu 2014; Zhou et al. 2014). Future studies can examine the relationships among servitisation, social capital, and 
performance in other countries with different cultural and institutional environments.

Second, a servitised firm may provide different types of services when implementing servitisation (Benedettini, Swink, and Neely 2015; Zhang et al. 2016; Saccani, Visintin, and Rapaccini 2014). Investigating the impacts of social capital and knowledge management on the profitability of different types of servitisation strategies can be an interesting topic. Third, this study measures servitisation using a dichotomous variable. Future studies can develop a scale to capture the extent of servitisation and empirically investigate how it affects the design of a firm's production system.

\section{References}

Adler, P.S., and S. Kwon. 2002. "Social capital: Prospects for a new concept." Academy of Management Review 27 (1):17-40.

Alghisi, A., and N. Saccani. 2015. "Internal and external alignment in the servitization journey - Overcoming the challenges." Production Planning \& Control 26 (1415):1219-32.

Baines, T., and H. Lightfoot. 2013. "Servitization of the manufacturing firm: Exploring the operations practices and technologies that deliver advanced services." International Journal of Operations \& Production Management 34 (1):2-35.

Baines, T., H. Lightfoot, O. Benedettin, and J.M. kay. 2009. "The servitization of manufacturing: A review of literature and reflection on future challenges." Journal of Manufacturing Technology Management 20 (5):547-67. 
Baines, T., H. Lightfoot, J. Peppard, M. Johnson, A. Tiwari, E. Shehab, and M. Swink. 2009. "Towards an operations strategy for product-centric servitization." International Journal of Operations \& Production Management 29 (5):494-519.

Baines, T., and V.G. Shi. 2015. "A Delphi study to explore the adoption of servitization in UK companies." Production Planning \& Control 26 (14/15):1171-87.

Bastl, M., M. Johnson, H. Lightfoot, and S. Evans. 2012. "Buyer-supplier relationships in a servitized environment: An examination with Cannon and Perreault's framework." International Journal of Operations \& Production Management 32 (6):650-75.

Benedettini, O., M. Swink, and A. Neely. 2015. "Why do servitized firms fail? A riskbased explanation." International Journal of Operations \& Production Management 35 (6): 946-79.

Brown, J. R., R.F. Lusch, and C.Y. Nicholson. 1995. "Power and relationship commitment: Their impact on marketing channel member performance." Journal of Retailing 71 (4):363-92.

Carey, S., B. Lawson, and D.R. Krause. 2011. "Social capital configuration, legal bonds and performance in buyer-supplier relationships." Journal of Operations Management 29 (4):277-88.

Chin, W. W. 2000. "Frequently asked questions - Partial least squares \& PLS-graph". Home Page.[On-line]. Available: http://disc-nt.cba.uh.edu/chin/plsfaq.htm

Chin, W. W. 2010. "How to write up and report PLS analyses." In Handbook of partial least squares: Concepts, methods and applications, edited by V. E. Vinzi, W. W. Chin, J. Henseler and H. Wang, 655-90. Berlin: Springer. 
Cousins, P.D., R.B. Handfield, B. Lawson, and K.J. Peterson. 2006. "Creating supply chain relational capital: The impact of formal and informal socialization processes." Journal of Operations Management 24 (6):851-63.

Cousins, P.D., and B. Lawson. 2007. "Sourcing strategy, supplier relationships and firm performance: An empirical investigation of UK organizations." British Journal of Management 18 (2):123-37.

Edelman, L.F., M. Bresnen, S. Newell, H. Scarbrough, and J. Swan. 2004. "The benefits and pitfalls of social capital: Empirical evidence from two organizations in the United Kingdom." British Journal of Management 2004 (Supplement 1):59-69.

Flynn, B.B., B. Huo, and X. Zhao. 2010. "The impact of supply chain integration on performance: a contingency and configuration approach." Journal of Operations Management 28 (1):58-71.

Fornell, C., and D.F. Larcker. 1981. "Evaluating structural equation models with unobservable variables and measurement error." Journal of Marketing Research 18 (1):29-50.

Ganesan, S. 1994. "Determinants of long-term orientation in buyer-seller relationships." Journal of Marketing 58 (2):1-19.

Hult, G.T.M., D. J. Ketchen, S. T. Cavusgil, and R.J. Calantone. 2006. "Knowledge as a strategic resource in supply chains." Journal of Operations Management 24 (5):458-75.

Hult, G.T.M., D.J. Ketchen, and S.F. Slater. 2004. "Information processing, knowledge development, and strategic supply chain performance." Academy of Management Journal 47 (2):241-53. 
Jansen, J.J.P., F.A.J. Van Den Bosch, and H.W. Volberda. 2005. "Managing potential and realized absorptive capacity: How do organizational antecedents matter?" Academy of Management Journal 48 (6):999-1015.

Johnson, M., and C. Mena. 2008. "Supply chain management for servitized products: A multi-industry case study." International Journal of Production Economics 114 (1):27-39.

Kastalli, I.V., and B. Van Looy. 2013. "Servitization: Disentangling the impact of service business model innovation on manufacturing firm performance." Journal of Operations Management 31 (4):169-80.

Kogut, B., and U. Zander. 1992. "Knowledge of the firm, combinative capabilities, and the replication of technology." Organization Science 3 (3):383-97.

Krause, D.R., R.B. Handfield, and B.B. Tyler. 2007. "The relationships between supplier development, commitment, social capital accumulation and performance improvement." Journal of Operations Management 25 (2):528-45.

Lawson, B., B.B. Tyler, and P.D. Cousins. 2008. "Antecedents and consequences of social capital on buyer performance improvement." Journal of Operations Management $26(3): 446-60$.

Li, Y., F. Ye, and C. Sheu. 2014. "Social capital, information sharing and performance: Evidence from China." International Journal of Operations \& Production Management 34 (11):1440-62.

Lightfoot, H., T. Baines, and P. Smart. 2013. "The servitization of manufacturing: A systematic literature review of interdependent trends." International Journal of Operations \& Production Management 33 (11/12):1408-34. 
Matthews, R.L., and P.E. Marzec. 2012. "Social capital, a theory for operations management: A systematic review of the evidence." International Journal of Production Research 50 (24):7081-99.

Nahapiet, J., and S. Ghoshal. 1998. "Social capital, intellectual capital, and the organizational advantage." Academy of Management Review 23 (2):242-66.

Neely, A. 2008. "Exploring the financial consequences of the servitization of manufacturing." Operations Management Research 1 (2):103-18.

Nunnally, J.C., and I.H. Bernstein. 1994. Psychometric Theory. third ed. New York: McGraw-HIll.

Oliva, R., and R. Kallenberg. 2003. "Managing the transition from products to services." International Journal of Service Industry Management 14 (2):160-72.

Opresnik, D., and M. Taisch. 2015. "The value of Big Data in servitization." International Journal of Production Economics 165:174-84.

Peng, D. X., and F. Lai. 2012. "Using partial least squares in operations management research: A practical guideline and summary of past research." Journal of Operations Management 30 (6):467-80.

Podsakoff, P.M., S.B. MacKenzie, J.Y. Lee, and N.P. Podsakoff. 2003. "Common method biases in behavioral research: A critical review of the literature and recommended remedies." Journal of Applied Psychology 88 (5):879-903.

Raddats, C., T. Baines, J. Burton, V.M. Story, and J. Zolkiewski. 2016. "Motivations for servitization: The impact of product complexity." International Journal of Operations \& Production Management 36 (5):572-91. 
Saccani, N., F. Visintin, and M. Rapaccini. 2014. "Investigating the linkages between service types and supplier relationships in servitized environments." International Journal of Production Economics 149:226-38.

Saunders, M., P. Lewis, and A. Thornhill. 2015. Research Methods for Business Students Seventh ed. Harlow:Pearson.

Shen, J., L. Wang, and Y. Sun. 2012. "Configuration of product extension services in servitisation using an ontology-based approach." International Journal of Production Research 50 (22):6469-88.

Shu, C., A.L. Page, S. Gao, and X. Jiang. 2012. "Managerial ties and firm innovation: Is knowledge creation a missing link?". Journal of Product Innovation Management 29 (1):125-43.

Slack, N., S. Chambers, and R. Johnson. 2010. Operations Management Sixth ed. Harlow: Pearson.

Smith, L., R. Maull, and I.C.L. Ng. 2014. "Servitization and operations management: A service dominant-logic approach." International Journal of Operations \& Production Management 34 (2):242-69.

Tsai, W., and S. Ghoshal. 1998. "Social capital and value creation: The role of intrafirm networks." Academy of Management Journal 41 (4):464-76.

Vandermerwe, S., and J. Rada. 1988. "Servitization of business: Adding value by adding services." European Management Journal 6 (4):314-24.

Villena, V.H., E. Revilla, and T.Y. Choi. 2011. "The dark side of buyer-supplier relationships: A social capital perspective." Journal of Operations Management 29 (6):561-76. 
Wang, P.P., X.G. Ming, D. Li, F.B. Kong, L. Wang, and Z.Y. Wu. 2011. "Status review and research strategies on product-service systems." International Journal of Production Research 49 (22):6863-83.

Wang, Z., F. Ye, and K.H. Tan. 2014. "Effects of managerial ties and trust on supply chain information sharing and supplier opportunism." International Journal of Production Research 52 (23):7046-61.

Ward, P.T., J.K. McCreery, L.P. Ritzman, and D. Sharma. 1998. "Competitive priorities in operations management." Decision Sciences 29 (4):1035-46.

Wise, R., and P. Baumgartner. 1999. "Go downstream: The new profit imperative in manufacturing." Harvard Business Review September/October:133-41.

Yeung, J.H.Y., W. Selen, M. Zhang, and B. Huo. 2009. "The effects of trust and coercive power on supplier integration." International Journal of Production Economics 120 (1):66-78.

Zahra, S.A., and G. George. 2002. "Absorptive capacity: A review, reconceptualization, and extension." Academy of Management Review 27 (2):185-203.

Zhang, M., X. Zhao, M. Lyles, and H. Guo. 2015. "Absorptive capacity and mass customization capability." International Journal of Operations \& Production Management 35 (9):1275-94.

Zhang, M., X. Zhao, C. Voss, and G. Zhu. 2016. "Innovating through services, co-creation and supplier integration: Cases from China." International Journal of Production Economics 171:289-300. 
Zhou, K. Z., Q Zhang, S. Sheng, E. Xie, and Y. Bao. 2014. "Are relational ties always good for knowledge acquisition? Buyer-supplier exchanges in China." Journal of Operations Management 32 (3):88-98. 


\section{Appendix. Measurement items}

\begin{tabular}{|c|c|}
\hline Measurement items & Factor loading* \\
\hline \multicolumn{2}{|l|}{ Social capital $(\alpha=0.862$, C.R. $=0.895, \mathrm{AVE}=0.549) * *$} \\
\hline We and our suppliers have compatible objectives and visions. & 0.717 \\
\hline We and our suppliers have shared values and culture. & 0.717 \\
\hline $\begin{array}{l}\text { We and our suppliers have common understandings about concepts } \\
\text { and codes. }\end{array}$ & 0.679 \\
\hline We trust our suppliers. & 0.812 \\
\hline Our suppliers have considered our interests when they made & 0.751 \\
\hline decisions. & 0.719 \\
\hline $\begin{array}{l}\text { We feel that our suppliers view us as being an important 'team } \\
\text { member', rather than being just another customer. }\end{array}$ & 0.784 \\
\hline \multicolumn{2}{|l|}{ We feel that our suppliers have been on our side. } \\
\hline Knowledge acquisition $(\alpha=0.818, \mathrm{C} . \mathrm{R} .=0.880, \mathrm{AVE}=0.648)$ & \\
\hline We frequently poll our suppliers to assess the quality of products. & 0.845 \\
\hline $\begin{array}{l}\text { We periodically organize special meetings with suppliers (e.g. focus } \\
\text { groups and brainstorming sessions) to find out what products are } \\
\text { needed in the future. }\end{array}$ & 0.842 \\
\hline $\begin{array}{l}\text { We have special mechanisms to gain suppliers' operational } \\
\text { information (e.g. production plan and inventory level) in real time. }\end{array}$ & 0.827 \\
\hline $\begin{array}{l}\text { We and our suppliers are connected by network-based information } \\
\text { systems. }\end{array}$ & 0.695 \\
\hline \multicolumn{2}{|l|}{ Knowledge combination $(\alpha=0.827, \mathrm{C} . \mathrm{R} .=0.879, \mathrm{AVE}=0.592)$} \\
\hline $\begin{array}{l}\text { We regularly organize learning groups to discuss the consequences of } \\
\text { new knowledge. }\end{array}$ & 0.797 \\
\hline $\begin{array}{l}\text { We have special procedures to distribute knowledge among functional } \\
\text { departments. }\end{array}$ & 0.728 \\
\hline $\begin{array}{l}\text { We have special training programs that help employees to grasp new } \\
\text { knowledge. }\end{array}$ & 0.778 \\
\hline $\begin{array}{l}\text { We frequently organize interdepartmental meetings to analyse and } \\
\text { interpret new knowledge. }\end{array}$ & 0.745 \\
\hline $\begin{array}{l}\text { We have special mechanisms for employees to integrate and combine } \\
\text { knowledge. }\end{array}$ & 0.795 \\
\hline \multicolumn{2}{|l|}{ Operational performance $(\alpha=0.858$, C.R. $=0.891, \mathrm{AVE}=0.540)$} \\
\hline Inventory turnover & 0.746 \\
\hline Unit manufacturing cost & 0.699 \\
\hline Stock-out cost & 0.731 \\
\hline Overall product quality & 0.659 \\
\hline Delivery speed & 0.784 \\
\hline Delivery dependability & 0.787 \\
\hline Volume flexibility & 0.729 \\
\hline
\end{tabular}

Note: * the $\mathrm{t}$ values for the factor loadings range from 12.038 to 38.072 .

$* * \alpha=$ Cronbach's Alpha; C.R.= Composite Reliability; AVE= Average Variance Extracted. 